\title{
Erratum to: Colorectal cancer screening: will non-invasive procedures triumph?
}

Timothy Church

\section{Erratum}

Unfortunately, the original version of this article [1] published with an incorrect citation. The article number has now been updated to $6: 125$, which is the correct citation for the article. The Publisher apologizes for any inconvenience caused.

Received: 7 July 2015 Accepted: 7 July 2015

Published online: 07 September 2015

\section{Reference}

1. Church T. Colorectal cancer screening: will non-invasive procedures triumph? Genome Med. 2014;6:125

Submit your next manuscript to BioMed Central and take full advantage of:

- Convenient online submission

- Thorough peer review

- No space constraints or color figure charges

- Immediate publication on acceptance

- Inclusion in PubMed, CAS, Scopus and Google Scholar

- Research which is freely available for redistribution 